\title{
DEFAMATION AND THE ART OF BACKFIRE
}

\author{
TRUDA GRAY AND BRIAN MARTIN*
}

[Legal discussions of defamation commonly focus on defamation law, with relative neglect of struggles that take place over defamation matters. To understand defamation struggles, we introduce backfire theory: if something is perceived as unjust and information about it is communicated to relevant audiences, it has the potential to backfire against those held responsible. Defamation suits have the potential to backfire when they are seen as oppressive or contrary to free speech. There are several types of actions by plaintiffs that can inhibit this backfire effect, including cover-up, devaluation of the defendant, reinterpretation and intimidation. To illustrate the value of backfire analysis of defamation struggles, we examine four Australian examples, involving author Avon Lovell, politician Robert Askin, solicitor John Marsden and Aboriginal leader Geoff Clark, and the British example of McDonald's suit against two activists. Participants in these struggles see the matters in terms of reputation and free speech; backfire analysis allows an observer to put tactics used by participants in a coherent framework.]

\section{INTRODUCTION}

The standard perspective on defamation law is that it is an attempt to balance the protection of two contrary values, reputation and free speech. On the one hand, defamation actions serve to penalise those who make inaccurate and malicious assaults on a person's reputation and to provide recompense to those whose reputations are unfairly tarnished. On the other, defamation laws must not be so restrictive that they restrain free speech, including public debate and investigative journalism that are essential for a well functioning democracy. This perspective frames most legal writings about defamation, which deal with facets of defamation law, the trajectories of particular cases,

\footnotetext{
* Truda Gray and Brian Martin work in the School of Social Sciences, Media and Communication, University of Wollongong NSW 2522. Truda is interested in corporate programmes for engineering consent. Brian has interest in non-violence, whistleblowing and participatory democracy. Emails: tgray@uow.edu.au; bmartin@uow.edu.au.

We thank Greg Ogle for valuable comments on a draft of this paper. This research was supported by the Australian Research Council.
} 
possibilities for law reform and the uses and abuses of defamation law for protecting reputations and hindering free speech.

This focus on the law of defamation is useful, but has the effect of diverting attention from a more practical matter: how struggles over reputation and over free speech are carried out; in particular how to understand the dynamics of such struggles. We use the word 'struggle' to signal that more is involved than matters of reputation, free speech and the law. Defamation issues are matters also of power, including the opportunity to publish one's views to mass audiences, the economic resources to pursue or defend legal actions, the social power to mobilise support and wage campaigns, and the coercive power to intimidate opponents.

We analyse defamation struggles using a different approach. We start with the observation that a defamation action can rebound against the plaintiff when it is perceived as unjust and information about it is widely communicated to relevant audiences, causing outrage. Such an outcome can be termed a backfire. Plaintiffs often take actions that inhibit outrage; defendants sometimes act in ways that amplify it. We use the term 'outrage' to refer to adverse reactions by individuals against something perceived as unjust or a norm violation. Thus the term outrage is a surrogate for various emotions including anger, disgust, disquiet and concern. We use the term 'backfire' to refer to the process by which outrage is turned into expression or action against whoever or whatever is perceived as responsible for the perceived injustice.

In the next section, we discuss backfire dynamics, first outlining its use in other fields and then how it can be applied to defamation. We next apply the backfire framework to several public cases involving actual or potential defamation suits. We conclude with comments on the implications of this approach to defamation matters.

\section{THE DYNAMICS OF BACKFIRE}

In a confrontation between protestors and heavily armed police, it might seem that the police inevitably have an overwhelming advantage in terms of imposing their will. In many situations this is true, but sometimes the actions of the police can rebound against them. If the protestors are seen to be peaceful and non-threatening, and the actions of the police excessive, this can mobilise greater support for the protestors, cause outrage among previously neutral observers and even cause concern among some of the police. 
A number of famous historical cases follow this pattern. In 1930, as part of the Indian independence struggle, Gandhi led what has been called the salt satyagraha, beginning with a march to the sea to produce salt in defiance of the British salt monopoly. During raids following the march, activists came forward and, without resisting, suffered brutal beatings by the police. This dramatic confrontation was reported by a US journalist, causing outrage worldwide and greatly weakening the credibility of British rule. ${ }^{1}$

In 1960 in South Africa, during nationwide protests against the government's pass laws, white police opened fire on the crowd in the town of Sharpeville, killing perhaps a hundred black Africans. The story, accompanied by photos taken by visiting journalists, produced headlines internationally and triggered a great increase in opposition to apartheid. ${ }^{2}$

In 1991 in Dili, the capital of East Timor, then occupied by Indonesia, troops opened fire on protestors at a funeral. The atrocity was witnessed by several western journalists and captured on videotape, which was later broadcast internationally. The Dili massacre led to a massive increase in international support for the East Timor independence movement. ${ }^{3}$

Nonviolence researcher Gene Sharp, who studied hundreds of campaigns, found this sort of reaction to attacks on nonviolent protesters to be such a regular occurrence that he included it as one of the stages in what he called 'the dynamics of nonviolent action'. Sharp called this effect 'political jiujitsu' by analogy with the sport of jiu-jitsu in which the force of the opponent is used against them. ${ }^{4}$ The concept of backfire is a generalisation of political jiu-jitsu beyond the field of nonviolent action.

In each of the cases mentioned, there appear to be two preconditions: a perceived injustice, namely brutal force against peaceful protestors, and communication to significant third party audiences. Although some attacks on nonviolent protestors rebound against the attackers, most do not. For example, there were many earlier atrocities in East Timor that attracted little attention. What actions by attackers are likely to inhibit outrage? By examining a range

\footnotetext{
${ }^{1}$ Thomas Weber, On the Salt March (1997).

2 Philip Frankel, An Ordinary Atrocity: Sharpeville and its Massacre (2001).

${ }^{3}$ Arnold S Kohen, From the Place of the Dead: The Epic Struggles of Bishop Belo of East Timor (1999).

${ }^{4}$ Gene Sharp, The Politics of Nonviolent Action (1973) 657.
} 
of cases, we can observe several types of methods that reduce or eliminate outrage. This approach to the issue is a form of grounded theory. ${ }^{5}$

The main methods used that inhibit outrage can be classified into five categories:

(1) Cover-up;

(2) Devaluation of the target;

(3) Reinterpretation of what happened;

(4) The use of official procedures to give an appearance of justice;

(5) Intimidation and bribery.

For example in the Sharpeville massacre, ${ }^{6}(1)$ police removed evidence that anti-personnel 'dumdum' bullets had been used, including destroying evidence of police stocks and removing bodies showing the characteristic damage from these bullets; (2) police and most of the white population in South Africa considered blacks to be inferior; (3) police claimed the crowd was menacing, whereas other observers had noted a playful mood; (4) the government immediately set up an official inquiry into the massacre, designed to be sympathetic to the government line but not too obviously subservient; (5) police, just after the massacre, arrested and threatened local activists, so few were willing to testify to the official inquiry, while the government declared a state of emergency. These actions dampened outrage from within both the black and the white South African communities, but were unable to prevent a huge international reaction to the massacre. This was principally because information about the events got out of the country and the international audience was not strongly influenced by the methods of devaluation, reinterpretation, legitimation by official inquiry, and intimidation.

Most or all of these five methods of inhibiting outrage are found not only in violent attacks against peaceful protestors but also in a wide range of other issues, including censorship, ${ }^{7}$ whistleblowing, ${ }^{8}$ dismissal of academics, ${ }^{9}$ police beatings, ${ }^{10}$ torture, ${ }^{11}$ and invasion of other countries such as Iraq. ${ }^{12}$

\footnotetext{
${ }^{5}$ Barney G Glaser and Anselm L Strauss, The Discovery of Grounded Theory: Strategies for Qualitative Research (1967).

${ }^{6}$ Frankel, above n 2.

${ }^{7}$ Sue Curry Jansen and Brian Martin, 'Making Censorship Backfire’ (July 2003) 7

Counterpoise 5; Sue Curry Jansen and Brian Martin, 'Exposing and Opposing Censorship: Backfire Dynamics in Freedom-of-speech Struggles' (2004) 10 Pacific Journalism Review 29.
} 
The common characteristic in these cases is a perceived injustice or a violation of a social norm. Violent attacks on peaceful protestors are widely seen as unjust; likewise, censorship is a violation of freedom of expression, a widely valued norm (at least in some societies), and a military attack on a non-threatening opponent is a violation of norms for international behaviour.

If perpetrators may employ these five major methods for inhibiting outrage, then targets have available corresponding avenues for countering the inhibition, for example by (1) exposing the action; (2) demonstrating the value of the target; (3) giving their own interpretation of events; (4) avoiding or discrediting official channels that give only an illusion of justice; (5) resisting and exposing intimidation and bribery.

Note that we are primarily concerned with perceived injustices and norm violations by powerful groups against those less powerful. Powerful groups have the capacity to inhibit outrage, at least in some cases. The opposite situation, in which a relatively powerless individual attacks a powerful group, almost inevitably backfires. For example, a man who randomly opens fire on his bosses seldom receives much sympathy and is unlikely to be able to draw on any of the five methods of inhibiting outrage.

This analysis, with a few modifications, can readily be applied to defamation. Suing for defamation can backfire if it is seen as oppressive or unjust - in particular as a threat to free speech - and if information about it is communicated to significant audiences. Consider in this regard the five main methods of inhibition:

\footnotetext{
${ }^{8}$ Brian Martin with Will Rifkin, 'The Dynamics of Employee Dissent: Whistleblowers and Organisational Jiu-jitsu’ (2004) 4 Public Organisation Review 221.

${ }^{9}$ Brian Martin, 'The Richardson Dismissal as an Academic Boomerang' in Kenneth Westhues (ed), Workplace Mobbing in Academe: Reports from Twenty Universities (2004) 317; Brian Martin, 'Boomerangs of Academic Freedom’ (June 2005) 6.2 Workplace: A Journal for Academic Labor, available at http://www.cust.educ.ubc.ca/workplace/issue6p2/steele.htm.

${ }^{10}$ Brian Martin, 'The Beating of Rodney King: The Dynamics of Backfire' (2005) 13 Critical Criminology 307.

${ }^{11}$ Brian Martin and Steve Wright, 'Countershock: Mobilising Resistance to Electroshock Weapons’ (2003) 19 Medicine, Conflict and Survival 205.

12 Brian Martin, 'Iraq Attack Backfire' (17 April 2004) 39 Economic and Political Weekly 1577.
} 
(1) Cover-up. Plaintiffs seldom publicise their actions; in offering a settlement, they often require defendants to sign a silencing clause.

(2) Defence lawyers commonly advise against seeking publicity, due to the risk of alienating the judge or of this being seen as evidence of malice.

(3) Devaluation of the target. Defamation law encourages denigration of the defendant to overcome claims made by the defence such as reasonableness and absence of malice. ${ }^{13}$

(4) Reinterpretation. Plaintiffs describe their purpose as defence of reputation, not suppression of free expression.

(5) Official channels. Plaintiffs use the law as a means of attack. The complexity and slowness of defamation law make it difficult to mobilise outrage against such attacks.

(6) Intimidation and bribery. Plaintiffs' threats and legal actions often intimidate defendants, while offers of settlement can operate like bribes.

In the analysis of defamation actions using the backfire model, there is one distinct difference from other applications. In the Sharpeville massacre and other such attacks, formal inquiries are commonly set up to defuse outrage by giving the appearance of justice. But in the case of defamation actions, official channels - namely the legal system - constitute the very means by which the attack is launched. The existence of defamation law gives, in advance, a degree of legitimacy to a certain category of threat to free expression.

\section{CASE Studies}

We now apply backfire analysis to several cases. The first case, Lovell, involved numerous defamation actions to prevent publication. The second, Askin, involved an implicit threat to sue media. The third, Marsden, involved a solicitor suing a television station. The fourth, Clark, involved a prominent person who, defamed in the media, decided not to sue. Finally, we describe the McLibel case, the most prominent case of backfire from a defamation action. There are other cases that can be readily analysed using the backfire model. ${ }^{14}$

\footnotetext{
${ }^{13}$ We thank Greg Ogle (personal communication, 10 November 2004) for this point.

${ }^{14}$ David Irving's suit to clear his reputation of the charge of being a Holocaust revisionist is a good example. See Richard J. Evans, Lying about Hitler: History, Holocaust and the David Irving Trial (2001). One of the most significant cases in Australia in recent years involved developers suing a wide range of critics of a plan to build a bridge to Hindmarsh Island, South Australia. We leave it to the reader to apply backfire analysis to this case. See Debra Jopson, 'A Bridge Writ Large', Sydney
} 
We have used cases from Australian and British jurisdictions where defamation law is widely seen as friendly to plaintiffs and hostile to free speech. ${ }^{15}$ However, the backfire framework should apply anywhere defamation actions can potentially be perceived as oppressive. SLAPPs (Strategic Lawsuits Against Public Participation), which are commonplace in the US, appear to fit the backfire model quite well. ${ }^{16}$ Similarly, the backfire model can be used to analyse legal actions, other than defamation, that are perceived as oppressive, such as the many types of legal action classified as SLAPPs.

It is worth emphasising that our analysis looks only at actions and their effects, not at motivations of the participants. For example, in looking at the first method of inhibition, cover-up, we examine ways in which actions taken by participants on one or both sides have the effect of limiting wider awareness of defamation actions and their consequences; this examination does not make assumptions about the motivations of the participants to cover up or reveal the activities. The very term 'cover-up' refers to cover-up as a consequence, not as an intention. This agnosticism about motivations is a general feature of backfire analysis, in which the focus is on the effects of actions. This is compatible with the view that everyone has the best of intentions. ${ }^{17}$

Morning Herald (Sydney), 2 March 1999, 14; ABC Radio National, 'Hindmarsh Island Defamation', The National Interest, 14 December 2003,

<http://www.abc.net.au/rn/talks/natint/stories/s1009598.htm> at 22 June 2006; Is This

Website Defamatory? (2004) Kumarangk Legal Defence Fund

$<$ http://green.net.au/hindmarsh/defamation.htm> at 22 June 2006; Tricky Legal

Business: The Impact of Legal Processes on the Campaign Against the Hindmarsh

Island Bridge (24 October 1998) Kumarangk Legal Defence Fund

<http://green.net.au/hindmarsh/tricky.htm> at 22 June 2006.

${ }^{15}$ On defamation matters in Australia, see Michael Newcity, 'The Sociology of Defamation in Australia and the United States' (1991) 26 Texas International Law Journal 1; Robert Pullan, Guilty Secrets: Free Speech and Defamation in Australia (1994); Brian Walters, Slapping on the Writs: Defamation, Developers and Community Activism (2003). On defamation matters in Britain, see Eric Barendt, Laurence Lustgarten, Kenneth Norrie and Hugh Stephenson, Libel and the Media: The Chilling Effect (1997); Fiona J L Donson, Legal Intimidation: A SLAPP in the Face of Democracy (2000); David Hooper, Reputations under Fire: Winners and Losers in the Libel Business (2000).

${ }^{16}$ George Pring and Penelope Canan, SLAPPs: Getting Sued for Speaking Out (1996). See also Seth Goodchild, 'Media Counteractions: Restoring the Balance to Modern Libel Law’ (1986) 75 Georgetown Law Journal 315.

${ }^{17}$ Roy F Baumeister, Evil: Inside Human Violence and Cruelty (1997) argues that usual perceptions of evildoers as malevolent or uncaring are wrong, and that instead they see themselves as victims or as justified in their actions. 


\section{A Avon Lovell and The Mickelberg Stitch}

In 1982, in a spectacular case in Western Australia, three brothers - Ray, Peter and Brian Mickelberg - were sentenced to prison for swindling gold from the Perth Mint. In 1985, journalist Avon Lovell published a book entitled The Mickelberg Stitch, ${ }^{18}$ in which he argued that the prosecution case against the Mickelbergs was based on questionable evidence. In other words, Lovell alleged the police had framed the brothers. With a big print run of 20,000, The Mickelberg Stitch sold rapidly in Perth until police threatened to sue the book's distributor and any bookseller or other business offering it for sale. The Police Union introduced a \$2 per week levy on its 5000 members to fund 40 legal actions against Lovell, the distributor and retailers. The defamation threats and actions effectively suppressed any general availability of the book. None of the suits against Lovell reached trial in over a decade; they remained active despite his repeated attempts to strike them out for lack of prosecution.

Eventually all suits were dropped in a settlement that was financially generous for Lovell and made no restrictions on distribution of the book. Lovell later convinced a retired detective, Tony Lewandowski, to publicly admit his role in framing the Mickelbergs by fabricating confessions. The convictions of the three brothers were quashed on appeal in 2004. ${ }^{19}$

Cover-up is central to this example. The police suits served to suppress availability of and publicity about Lovell's book and also discouraged media attention to the cover-up process. According to Lovell (personal communication, 13 November 2004), he was devalued through the presumption of the courts that the police were right and he was wrong. In addition, he says police spread rumours to journalists that he was not a real journalist, was involved in compromising sexual affairs and so forth. The suits reinterpreted the issue from a debate about an alleged police frame-up to a legal matter. The official channels of the legal system were the method of attack: Lovell was tied up by the suits (including countersuits, there were eventually 82 actions), making over 1000 court appearances in a decade. The actions served as a method of intimidating any author, publisher or bookseller that might have wanted to pursue the story. According to Lovell, other methods of intimidation were used against him, including loosening wheel

\footnotetext{
${ }^{18}$ Avon Lovell, The Mickelberg Stitch (1985). See also Avon Lovell, Split Image: International Mystery of the Mickelberg Affair (1990)

${ }^{19}$ Andrea Mayes and David King, 'Court Quashes Brothers' Convictions for 1982 Perth Mint Swindle’, The Weekend Australian (Sydney), 3-4 July 2004, 8.
} 
bolts on his car, which could have led to a serious accident. Thus all the methods of inhibiting outrage were present in this case.

Lovell's many court appearances did little to amplify outrage. On the other hand, by convincing Lewandowski to admit to a police frame-up, Lovell was dramatically successful in reopening public discussion of the case. Lovell's most effective counter to the defamation suits therefore was publicity, not court appearances.

\section{B Robert Askin}

Robert Askin was premier of New South Wales from 1965 to 1975. Among journalists and others, he was widely known to be involved in criminal activities, but the media were unwilling to publish anything about this due to Australia's restrictive defamation laws. Shortly after Askin died in 1981, The National Times — a weekly newspaper that featured much investigative journalism — published a story by journalist David Hickie titled 'Askin: Friend to Organised Crime'. The opening paragraphs of this article give ample testimony to the power of defamation law to inhibit free speech:

Sir Robert Askin was an underestimated man. The mark he left on this country was considerable - and has never publicly been discussed. While Sir Robert Askin was in power, organised crime became institutionalised on a large scale in New South Wales for the first time. Sydney became, and has remained, the crime capital of Australia. Askin was central to this. His links with three major crime figures [Perce] Galea, close friend Joe Taylor and another, allowed the transformation of Sydney's baccarat clubs into fully-fledged casinos.

Askin's links with corrupt police allowed these casinos and SP [starting price] betting to flourish. The corrupt police included commissioners Allan and Hanson.

According to a reliable source very high in the old Galea empire, Askin and Hanson were paid approximately $\$ 100,000$ each in bribes a year from the end of the Sydney gang wars in 1967-68 until Askin's retirement. The source is impeccable. This information has not been available for The National Times to use until Askin's death...

Only now that Askin is dead can the recent history of NSW be explored publicly. It is not a time for holding back, despite the distress these revelations may cause Askin's colleagues and family.

Such are the laws of defamation in this country, that only a royal commission or parliamentary debate could fully protect public discussion about the Askin years while the man lived. Recent commissions into organised crime have never dealt publicly with Askin's role. ${ }^{20}$

${ }^{20}$ David Hickie, 'Askin: Friend to Organised Crime' The National Times (Sydney), 13-19 September 1981, 1. 
The article went on to give details about criminal operations in New South Wales and Askin's role in them. ${ }^{21}$ Subsequently, there was a major debate in the Sydney Morning Herald about Askin's personal involvement, such as whether he had regularly received bundles of cash in brown paper bags, but there seemed no disagreement about the expansion of criminal activity during his term as premier. This case clearly shows how defamation law can inhibit open discussion of matters of great public import.

This case reveals several methods by which outrage over the injustice of this process was inhibited. The likelihood that Askin would sue for defamation served to intimidate the media. Neither Askin nor the media discussed this likelihood, so the role of defamation law was covered up, as were Askin's activities. After Askin's death, The National Times explicitly linked defamation law and cover-up; the alternative interpretation, built into the law itself, is that the key issue was protection of Askin's reputation. Defamation law was the official channel by which free speech was inhibited. As noted in the article, ways around the law, such as comment in parliament protected by parliamentary privilege, were not used. Askin, as leader of the government, would have had formidable power to attack parliamentary critics. The only technique of inhibiting outrage not obviously involved was devaluation; it was less relevant because cover-up was so effective.

It is worth noting that in this case, defamation law was only one of the means for covering up discussion of criminal activity. When organised crime and corrupt police are involved, anyone who speaks out can be in jeopardy, as illustrated in the following extract from Hickie's article:

In April 1967 Askin was handed a statutory declaration by a Mr B. Ng containing allegations of police complicity with members of organised crime syndicates in Sydney's Chinatown involved in unlicensed gambling, smuggling of narcotics and counterfeit money.

The Ng controversy lasted for two years. Ng and his lawyer were harassed and even threatened with death. At last Askin refused an inquiry into Chinatown on the basis of a report from [Police] Commissioner Allan.

Hatton [John Hatton, independent member of state parliament] subsequently told parliament that independent opinions obtained from Ken Marks QC ... and two other leading interstate counsel had concluded that Allan's report was a 'carefully compiled and intelligent whitewash that should be categorised as dishonest and a derogation of duty to the public to ventilate serious matters. ${ }^{22}$

\footnotetext{
${ }^{21}$ Hickie later explored Askin's criminal connections in more depth in David Hickie, The Prince and the Premier: The Story of Perce Galea, Bob Askin and the Others Who Gave Organised Crime its Start in Australia (1985).

${ }^{22}$ Hickie, above n 20, 8.
} 
The Ng episode illustrates the use of both intimidation and official channels to inhibit outrage.

\section{John Marsden}

John Marsden was one of a group of prominent Sydney figures rumoured to be engaged in paedophilia. Channel Seven, one of the principal Australian television networks, aired specific allegations against Marsden in two programmes in 1995 and 1996. ${ }^{23}$ Marsden was a well known and, in some eyes, an infamous character on the Sydney scene. As a solicitor his name had been associated with many high-profile court cases. He was a past president of the New South Wales Law Society and had been a member of the Police Board. He moved amongst a powerful elite as an open homosexual.

After the Channel Seven broadcasts, Marsden sued for defamation, denying the allegations and claiming he would clear his reputation in court. However, what he thought would be a quick victory turned into a public saga, expanding into Australia's longest ever defamation case. ${ }^{24}$

The entire process, including initial injunctions against Channel Seven, the defamation trial and various appeals, lasted over six years. Channel Seven and other media publicised the court proceedings and the evidence from witnesses, keeping the details of the allegations against Marsden in the public eye.

By the time the court finally found against Channel Seven and awarded Marsden damages and costs, the damage had been amplified beyond

${ }^{23}$ The programmes were Today Tonight, 13 March 1995, and Witness, 7 May 1996. See Kate McClymont, 'Marsden’s Bitter-sweet Victory: 'Forever Tainted’’ (28 June 2001) Sydney Morning Herald 1; ABC Radio, 'Defamation Case Has Ruined my Life and Reputation: Marsden', 7.30 Report, 20 July 2000,

<http://www.abc.net.au/7.30/stories/s154345.htm> at 22 June 2006.

${ }^{24}$ Marsden commenced action against Channel Seven (Amalgamated Television Services) on 14 March 1995, when he sought to restrain it from broadcasting a second programme (Witness, actually broadcast in 1996). The main defamation action, which began in February 1999, concerned allegations made in a segment of the 13 March 1995 Today Tonight broadcast. See John Marsden v Amalgamated Television Services Pty Ltd S.96/004 (Unreported, High Court of Australia, Gummow J, 2 \& 3 May 1996). The final judgement was handed down in June 2001: Marsden v Amalgamated Television Services Pty Ltd 510 (Unreported, Supreme Court of NSW, Levine J, 2001). 
salvation. ${ }^{25}$ Technically Marsden had won the case but both his reputation and his health had been severely damaged, and along the way he was financially stretched. ${ }^{26}$ His reputation was not restored by the victory, which has been described as 'pyrrhic.' 27

We now examine the five methods of inhibiting outrage and the corresponding methods of amplifying outrage in relation to this case.

\section{Cover-up}

Usually media organisations do not publicise defamation actions against themselves. In this case Seven took the opposite tack. It led with the allegations against Marsden and continued to publicise the trial and details of the unfolding evidence. Other media, protected by the qualified privilege of being able to report court proceedings and enticed by the controversial public persona of Marsden, followed suit. New witnesses and police evidence were brought forward throughout the trial. In the course of this, myriad details of Marsden's life and personal proclivities came under the microscope.

By the end of the trial the initial allegations and the unfolding details of Marsden's life were being broadcast and discussed far beyond the original, mainly Sydney-based, audience for the initial programs aired by Channel Seven. Marsden observed that he 'never thought it would be like this. I thought it would be over in six weeks. ${ }^{28}$

\section{Devaluation of the target}

While Channel Seven came under some scrutiny and criticism for its journalistic practices and its motives for publicising the allegations against Marsden, it was Marsden himself who came under the greatest scrutiny and criticism.

Marsden was continually devalued by the unfolding evidence and the testimony of witnesses against him and from his own admissions, seen as damning in some people's eyes. He admitted he was promiscuous and used

\footnotetext{
${ }^{25}$ McClymont, above n 23.

${ }^{26}$ John Marsden, I Am What I Am: My Life and Curious Times (2004) 284, 343, 359.

${ }^{27}$ Channel Nine Television, ‘A Matter of Honour: John Marsden’, Sixty Minutes, 1 July 2001, $<$ http://sixtyminutes.ninemsn.com.au/sixtyminutes/stories/2001_07_01/story_360.asp $>$ at 22 June 2006.

${ }^{28}$ ABC Radio, above n 23.
} 
drugs. He denied allegations of paedophilia but acknowledged his habit of taking casual sexual partners home and not, as he put it, checking their birth certificates.

Further, during the course of the trial Marsden approached some of the witnesses. The media presented this as an improper way of behaving. Marsden argued in his own defence that 'I was entitled. There's no fence around a witness ... I'm a lawyer and I acted properly and with proper consideration of the legal requirements. ${ }^{29}$ The overall effect of this was to devalue the plaintiff rather than the defendant.

\section{Reinterpretation}

Marsden tried to reframe the public and political issues of paedophilia into the private and legal issues of protection of reputation. But in this case the reframing failed. This was no doubt due to Marsden's own high profile and the public's salacious interest in details of sexual behaviour that were the subject of the trial, combined with Channel Seven's willingness to use its power as a major media organisation to promote its perspective.

\section{Official Channels}

Commissions of inquiry and court cases often work to turn contentious public political issues into closed private proceedings, thereby defusing the political heat. The Marsden trial had the opposite effect. The legal proceedings made what was already sensational even more so by fuelling it with a welter of unfolding details about Marsden's life and practices.

\section{Intimidation}

Far from intimidating Channel Seven, the defamation proceedings gave it further opportunity to air the allegations and to publicise material about Marsden. There was great public interest in the case and it made good copy. Channel Seven had a large team of lawyers and resources to call on for handling such legal challenges.

In July 2000, before the end of the legal process, Marsden stated: '[i]t's probably totally ruined my life and my health. It's certainly ruined me financially. I've lost a lot of friends. I live on medication. I - I go through horrendous dreams. ${ }^{30}$ Given this assessment, one might conclude it was Marsden who was more intimidated by the whole process.

\footnotetext{
${ }^{29}$ Ibid.

${ }^{30}$ Ibid.
} 
In summary, Marsden's use of defamation proceedings to silence those who were criticising him seriously backfired. In this regard, journalist Kate McClymont commented that 'in the cold light of day, the court case - to seek compensation for the damage to his reputation - was far more damaging and personally humiliating than either of Channel Seven's two programs ever were. ${ }^{31}$ Although he won legally, his reputation was further damaged. A satirical publication remarked that Marsden should now sue himself for defamation. ${ }^{32}$ Marsden in his autobiography stated that he 'wanted to highlight the failures of the legal system to protect people who have been subject to outrageous defamation. ${ }^{33}$

Marsden died of cancer in May 2006. Media reports included praise and some fierce criticism, including new revelations about sex with underage males. ${ }^{34}$ Marsden's defamation action had created sufficient interest in his behaviour, especially in the media, that his reputation came under further attack. This can be regarded as an extension of the backfire from his defamation case.

\section{Geoff Clark}

Geoff Clark, an Aboriginal activist, was head of the Aboriginal and Torres Strait Islander Commission (ATSIC), the highest level Aboriginal peak body in Australia. In 2001, the Melbourne newspaper The Age, one of Australia's most prestigious dailies, published a front-page article titled 'Geoff Clark: Power and Rape ${ }^{, 35}$ alleging that in the 1970s and 1980s Clark had raped four women.

Clark denied the allegations, claiming The Age 'have (sic) surpassed the bounds of reporting and have constituted themselves (sic) as judge, jury and

${ }^{31}$ Kate McClymont, 'Got the Money, Lost the Name: How John Marsden Won a Court Case and Destroyed his own Reputation', Sydney Morning Herald (Sydney), 28 June 2001, 13.

32 'Marsden Now to Sue Himself: 'Court Action Sullied My Reputation'”, (2001) 42 The Chaser.

${ }^{33}$ Marsden, above n 26, 1.

${ }^{34}$ Among the critical commentaries are Paul Sheehan, 'Case for the Damnation of Marsden’ Sydney Morning Herald (Sydney), 22 May 2006, 11; Ron Hicks, 'Painful Memories Hard to Erase' Weekend Australian, 17 June 2006, 23.

${ }^{35}$ Andrew Rule, 'Geoff Clark: Power and Rape' The Age (Melbourne), 14 June 2001, 1. 
executioner. ${ }^{36}$ In response to accusations that it was conducting a 'trial by media,' The Age justified its publication of the story by claiming the public had a right to know, the allegations were true and Clarke had never been brought to trial. The story engendered a lot of public discussion, specifically from legal groups, women's groups, media organisations, journalists and Aboriginal groups. The combination of the role of the law, the media, race, sexual politics and crime was explosive.

Clark accused the media, particularly the Fairfax company, the owner of The Age, of carrying out a campaign of vilification against him and other leaders of Aboriginal organisations in order to discredit and destroy Aboriginal organisations such as ATSIC and to reduce his personal political position.

Michael Gawenda, the editor of The Age, challenged Clark to use defamation proceedings to clear his name and called on the Prime Minister to intervene and for Clark to stand down from his position at the head of ATSIC.

Clark did not sue for defamation. He claimed the cost was prohibitive and the delay in achieving any outcome would be too great. ${ }^{37}$ It is reasonable to surmise that a defamation suit would have played into the hands of his accusers, giving them an opportunity to further publicise the claims and to increase sales. In other words, there was a high probability that a defamation action would have backfired. By not suing, Clark may well have avoided a saga like that endured by Marsden.

\section{E McLibel}

The McLibel case is the most famous example of defamation action backfiring on the initiator. ${ }^{38}$ McLibel refers to the case of McDonald's versus two activists, Helen Steel and Dave Morris. In the late 1980s, Steel and

\footnotetext{
${ }^{36}$ Michelle Tesoriero, ‘Trial by Media' (July 2002) Reportage (Australian Centre for Independent Journalism) <http://www.reportage.uts.edu.au/analysis/geoffclark.html> at 22 June 2006.

${ }^{37}$ Debra Jopson, 'The Power of Silence' Spectrum, Sydney Morning Herald (Sydney), 8-9 June 2002, 4.

${ }^{38}$ This became the longest running case in British legal history. See Dave Morris, 'McLibel: Do-It-Yourself JUSTICE' (1999) McSpotlight

<http:/www.mcspotlight.org/media/press/msc_diyjustice.html> at 22 June 2006. For an earlier treatment of McLibel in backfire terms - as a censorship backfire — see Jansen and Martin, 2003, above n 7.
} 
Morris and other members of the anarchist group London Greenpeace ${ }^{39}$ produced and distributed a leaflet outside McDonald's restaurants called 'What's Wrong With McDonald's: Everything They Don't Want You to Know. ${ }^{, 40}$ The leaflet covered a number of topics including nutrition, labour practices, cruelty to animals and environmental damage. McDonald's sued the activists for defamation, claiming numerous statements in the leaflet were false. $^{41}$

McDonald's was renowned for using defamation actions to silence critics; the case against London Greenpeace was but one of its many actions and threats over the years. ${ }^{42}$ Usually McDonald's had been successful in damping down critical comment but this case did not go to plan. Steel and Morris decided to stand their ground and fight the action. With only occasional legal advice from a pro bono lawyer, they did so on their own and with very limited resources. The public interest in McDonald's and in the issues raised by the trial, and particularly in the spectacle of the two individuals standing before the onslaught of the financial and legal power of such a powerful corporation, increased public attention.

\section{Cover-up}

McDonald's tried to shut down the activists' criticisms both by instituting the defamation proceedings and in subsequent settlement offers. In media statements after the trial began, McDonald's said it had started the legal action to stop the publication of the leaflet and its resultant publicity. ${ }^{43}$ Two months into the trial, McDonald's contacted the defendants Steel and Morris to try to get them to pull out and agree to a settlement. McDonald's offered to pay 'a substantial sum' to a mutually agreed third party on the condition that Steel and Morris sign a promise to never again make any public criticism of McDonald's. This offer was rejected by Steel and Morris and rejected again a year later when McDonald's repeated the offer. ${ }^{44}$ As the defendants pointed out, '[t]he whole reason we are fighting the case was to defend our right to criticise them and other multinationals, so we are hardly going to agree to gag ourselves. $^{45}$

\footnotetext{
${ }^{39}$ Not affiliated with Greenpeace International.

${ }^{40}$ See copies of this leaflet on the website <http://www.mcspotlight.org >

${ }^{41}$ McDonald's Corporation \& McDonald's Restaurants Ltd. v Helen Steel \& David Morris [1997] EWHC QB 336.

${ }^{42}$ Donson, above n 15 , especially chs 5 \& 6 .

${ }^{43}$ Ibid 89.

${ }^{44}$ Ibid 91.

${ }^{45}$ John Vidal, McLibel (1997) 126.
} 
If McDonald's aim was to silence criticism, its actions had the effect of galvanising it. Massive publicity about the case was generated. A very effective support group was established to help with the court case and to publicise the issues involved. This was achieved with minimal resources but with remarkable organisation. A website, McSpotlight, was set up to give people around the world access to details of the trial as it proceeded and information about the issues raised. ${ }^{46}$ The offending leaflet was translated into 27 languages and was distributed in the millions by bands of people who signed up to continue what McDonald's was trying to prevent.

In the face of the rising publicity, McDonald's, in desperation, tried to avoid media exposure when it could, refusing to speak to some programs and to particular journalists. ${ }^{47}$

McDonald's efforts at cover-up extended to the court proceedings. The corporation made every effort to keep documents and evidence out of the trial, The company had evidence presented by Steel and Morris struck out on various technical legal grounds, only to have it reinstated when Steel and Morris won their appeal against this. ${ }^{48}$ Morris commented that he and Steel had 'a constant battle to get McDonald's to hand over all the relevant documents in their possession - as they should have done before the case began, but were still being forced to do right up to the end. ${ }^{49}$ As it turned out, the defendants were able to use the court processes to obtain and make public many documents damaging to McDonald's and to cross-examine expert witnesses to the same effect.

\section{Devaluation of the target}

A defamation action carries with it the implication that the defendant has done something illegal, even reprehensible. McDonald's attempted to portray the activists in this way and to present their criticism as unjustified. McDonald's published its own leaflet attacking the criticisms made in the London Greenpeace leaflet and calling the defendants Steel and Morris liars. However

\footnotetext{
${ }^{46}$ McSpotlight <http://www.mcspotlight.org>. The site, set up on 16 February 1996, was accessed more than one million times in the first month and by mid 2003 the site had been accessed over 184 million times. See The McLibel Trial Story (2004) McSpotlight <http://www.mcspotlight.org/case/trial/story.html> at 22 June 2006.

${ }^{47}$ A confidential 1995 memo from McDonald's Australia, leaked to Australian television programme Sixty Minutes, said 'We could worsen the controversy by adding our opinion’: Morris, above n 38.

${ }^{48}$ Donson, above $\mathrm{n} 15,88$.

${ }^{49}$ Morris, above n 38.
} 
this representation did not stand up to public scrutiny. The corporation itself was devalued for its bullying tactics which were apparent to the public; furthermore, the inequality in financial and legal resources offended many people's sense of fair play. The importance of free speech in a democracy was at issue and the corporation appeared to be attempting to suppress a public right. The public's image of McDonald's was lowered and that of the defendants was enhanced.

\section{Reinterpretation}

McDonald's, through its legal action, attempted to recast the issue as one protection of reputation. The defendants were far more successful in portraying the issue as one of free speech versus censorship. Helen Steel, in her submission to the court stated that: 'We feel there is one word that can sum up what this case is about, and that is censorship. McDonald's is using the libel laws of this country to censor and silence their critics. ${ }^{50}$

\section{Official Channels}

The use of official channels reverberated against McDonald's. Its reputation, which was technically being protected in court, was impugned for the very act of initiating the defamation action. The corporation's use of this channel to attack was obvious to the public. The attempt to turn a public issue into a legal matter was countered by the defendants and their support group who were able to continually keep the issues before the public by publicising the trial proceedings.

\section{Intimidation}

Over the years McDonald's had issued so many threats and legal actions against critics that it had created a general fear of the repercussions of criticising the corporation. ${ }^{51}$ The intimidating prospect of defending themselves against such a corporation prompted three of the initial five activists who were sued in the McLibel case to withdraw and apologise to McDonald's. Helen Steel commented that, 'It just really stuck in the throat to apologise to McDonald's. I thought it was them that should have been apologising to us - well not us specifically, but to society for the damage they do to society and the environment. ${ }^{, 52}$

\footnotetext{
${ }^{50}$ Donson, above n 15, 98.

${ }^{51}$ McDonald's Censorship Strategy (2005) McSpotlight

<http://www.mcspotlight.org/company/other_mclibels/index.html> at 22 June 2006.

52 ‘The McLibel Trial Story,' above n 46.
} 
When McDonald's published and distributed its own leaflet against the defendants, Steel and Morris counter-sued the corporation for defamation. The two defendants stood against the team of corporate lawyers and the resources of McDonald's. Legal commentator Marcel Berlins observed that he 'cannot think of a case in which the legal cards have been so spectacularly stacked against one party. ${ }^{, 53}$

In legal terms, the original Mclibel case resulted in a mixed outcome for both sides. Five of the original claims were considered proven against McDonald's ${ }^{54}$ and eight were considered unproven. McDonald's was by this time trying to minimise the publicity surrounding the trial and did not pursue damages and dropped its claim for costs. ${ }^{55}$

Although the corporation was awarded damages and technically won on a number of legal points, the case was as a public relations disaster. Its action against the two activists was viewed by many observers as unfair. The public interest in the trial and the issues raised were far reaching. What McDonald's hoped would be a private legal knock down of the two defendants turned into what Morris described as a 'public issue fought and won in the court of public opinion and on the street. ${ }^{, 56}$ In summary, the legal action by McDonald's backfired spectacularly.

As a final turn, Steel and Morris took the British government to the European Court of Human Rights, claiming their freedom of speech had been curtailed because of Britain's defamation laws. In February 2005 the court upheld their claims, ruling that the two activists should have been given legal aid.

\section{DISCUSSION AND CONCLUSION}

The backfire framework, developed to analyse the dynamics of injustice in a range of areas, can be extended to the study of defamation threats and suits. There are two key requirements for an action to backfire on its originators: it must be perceived as unjust or excessive, and it must be communicated to significant audiences. The McLibel case is the best example of defamation

\footnotetext{
${ }^{53}$ Morris, above n 38.

54 The court held that McDonald's advertisements exploited children, that McDonald's was responsible for cruelty to animals and that it paid low wages and was antagonistic to trade unions.

${ }^{55}$ McLibel Trial Judgement (2004) McSpotlight

<http://www.mcspotlight.org/case/trial/verdict/index.html> at 22 June 2006.

${ }^{56}$ Morris, above n 38.
} 
action backfire: the high-powered suit by McDonald's was seen as disproportionate to the actions of the two indigent defendants, and a major anti-McDonald's campaign grew up around the case, symbolised by the McSpotlight website.

However, most actions do not backfire, even when they have the potential to do so. Perpetrators can take a number of types of actions that inhibit outrage: cover-up, devaluation of the target, reinterpretation of the action, use of official channels, and intimidation and bribery. These types of actions are found in a wide variety of situations, including police beatings and wars. They are also found in many defamation actions. Cover-up occurs when the plaintiff or the defendant, or both, keep the action out of the public eye. Sometimes those threatened with defamation actions do not publicise them because it is easier to acquiesce than to organise publicity. For example, when West Australian police threatened bookshops selling Avon Lovell's book The Mickelberg Stitch, it is understandable that they might just acquiesce: their main business was selling books, not opposing censorship.

Devaluation of the target is implicit in the charge of defamation, because the defendant is alleged to be engaged in illegal activity. Inside the court, efforts to demonstrate the defendant's malice can cause devaluation. Additional devaluation often occurs behind the scenes through circulation of rumours. In cases that backfire, it is the reputation of the plaintiff that suffers, as in the McLibel case and also John Marsden's disastrous suit against Channel Seven.

Reinterpretation of the action is built into the charge of defamation: the defendant frequently claims to have been exercising free speech; the suit redefines the action as an attack on reputation.

Defamation actions use the legal system as a means of attack. Given that laws and courts are widely perceived as providing justice, this provides a powerful means of legitimating the attack and inhibiting outrage.

Finally, defamation actions are potent means of intimidation. Indeed, merely the threat of a defamation action often operates to inhibit people from speaking out. Intimidation thus links closely with cover-up. Bribery also plays a role: a settlement often reduces a defendant's incentive to act against the injustice of a defamation suit, and the silencing clauses in many settlements enforce cover-up.

Importantly, two of the key means of inhibiting outrage are inherent in defamation law: the interpretation that the issue is one of reputation and the 
fact that defamation law has the status of law, with all the advantages of official credibility that attach to that. It is also significant that defamation suits, and sometimes just threats, intimidate many people.

If there are five methods of inhibiting outrage, then by turning each one on its head we arrive at five methods of countering inhibition: publicise the action, validate the worth of the target, interpret the action as a violation of free speech, discredit the courts as a means of obtaining justice (at least in relation to free speech and reputation), and refuse to be intimidated or bribed. As a result of the huge personal commitment by the defendants Steel and Morris, as well as the efforts of their supporters, the McLibel case illustrates each of these counter-measures.

Legal attacks can be turned into opportunities for the defence, either in court ${ }^{57}$ or in the public domain. More generally, the backfire framework points to those tactics that are most effective for plaintiffs and those that work best for their opponents. The framework offers some object lessons for those who are rich and powerful: be careful about suing when the action can be perceived as excessive and when there is someone who will mount a determined resistance. Large corporations have already learned from McDonald's public relations disaster.

For individuals inclined to sue media organisations for attacks on their reputations, there is a great risk: the ensuing case can be used to further damage one's reputation, sometimes dramatically. This is the lesson from John Marsden's suit against Channel Seven: he won the legal case but ended up with his reputation damaged far more than before. Geoff Clark, who was seriously defamed in the media, decided not to sue, thus avoiding this risk.

For free speech advocates, the backfire model gives guidance on tactics. A key message is to take the issues to wider audiences, thereby resisting coverup and intimidation. As well, taking the issue to wider audiences reduces the

\footnotetext{
${ }^{57}$ Greg Ogle (personal communication, 10 November 2004) suggests a number of tactics for defendants that use a backfire dynamic:

- making a counterclaim based on an affidavit filed by the plaintiff;

- drawing on an affidavit filed by the plaintiff to seek documents through discovery;

- allowing an argument to proceed through to contempt charges, then pointing out a fault in the service of a document;

- making a statement that encourages a potential plaintiff to sue, with the suit likely to hurt the plaintiff's reputation;

- encouraging an injunction that draws media attention to the item in question.
} 
narrowing of the issue to the legal forum, where plaintiffs have the advantage of legal legitimacy. In the words of one commentator, 'Once you start thinking of the case as a legal matter rather than a political issue, you have started to lose - politically and legally. ${ }^{, 58}$

${ }^{58}$ Greg Ogle, ‘The Bush Lawyer’s Guide to Responding to Legal Threats and Litigation’ <http://users.senet.com.au/ gregogle/Responding.html> at 22 June 2006. 